Special Issue on

Public Sector Productivity and Competitiveness

Public Enterprise

Volume 24, Issue 1, 2019

https://doi.org/10.21571/pehyj.2019.2401.01

\title{
Bolder Disinvestment or Better Performance Contracts? Which Way Forward for India's State-Owned Enterprises
}

\author{
Ajay Chhibber \\ National Institute of Public Finance and Policy, New Delhi, India \\ Institute of International Economic Policy, George Washington University, Washington, DC, USA \\ Swati Gupta \\ National Institute of Public Finance and Policy, New Delhi, India
}

Received March 2018; Revised January 2019; Accepted January 2019

\begin{abstract}
This paper analyses the performance of India's Public Sector Undertakings (PSUs) using measures of labour and overall efficiency and productivity indicators as opposed to financial returns. Using methods that correct for selection bias, the results show that performance contracts do not improve firm efficiency, but disinvestment has a very strong positive effect on firm efficiency. Disinvestment improves labour productivity and efficiency, which is not surprising, but it also improves overall efficiency. India should pursue much bolder privatization even of PSUs which claim to be making operational profits - such as Air India, because privatization improves overall firm efficiency and unlocks capital for use elsewhere, especially in public infrastructure, and reduces the possibility of political interference in their functioning in the future.

Keywords: Disinvestment (privatization), MOU (performance contract), public sector restructuring, public sector undertakings, state owned enterprises.

Reference to this paper should be made as follows: Chhibber, A. \& Gupta, S. (2019). Bolder Disinvestment or Better Performance Contracts? Which Way Forward for India's State-Owned Enterprises. Public

Enterprise, 24(1), 1-22.
\end{abstract}




\section{Introduction}

Since the 1980s, the number of public sector undertakings (PSUs) in India has varied between 213 and 241. Of these, 7 largest PSUs are called Maha Ratnas, 17 are called Nav Ratnas, and 73 are given the title of Mini Ratnas. The remainder has no classification as such. About half of them are in manufacturing and mining and the rest are in the service sector - transport, telecommunications, financial services, and so on (service sector PSUs are about 106, while those in the non-service sector are 129). These are the remnants of India's socialistic legacy from the Nehru-Gandhi era.

The combined asset of all PSUs was around 35\% of GDP in 1990 but by 2015 had declined to just over $20 \%$ of GDP (Figure 1). Over the same period, the sales to GDP ratio declined from $20 \%$ of GDP in 1990 to about $16 \%$ of GDP in 2015 , a much smaller decline indicating that the sales to asset ratio increased from 0.5 in 1990 to around 0.8 in 2015. Value added, created by PSUs, as a share of GDP and the ratio of PSU employment to total organized employment in the economy declined from around 8\% of GDP in 1990 to under 5\% of GDP by 2015. Post the economic reforms of 1991, although the number of PSUs has remained more or less the same, their share in the economy measured by value added, employment and sales has declined, as the private sector has expanded faster. This is a pattern we see in several other countries with State capitalism such as in Brazil and China, where the share of State enterprises has also been declining.

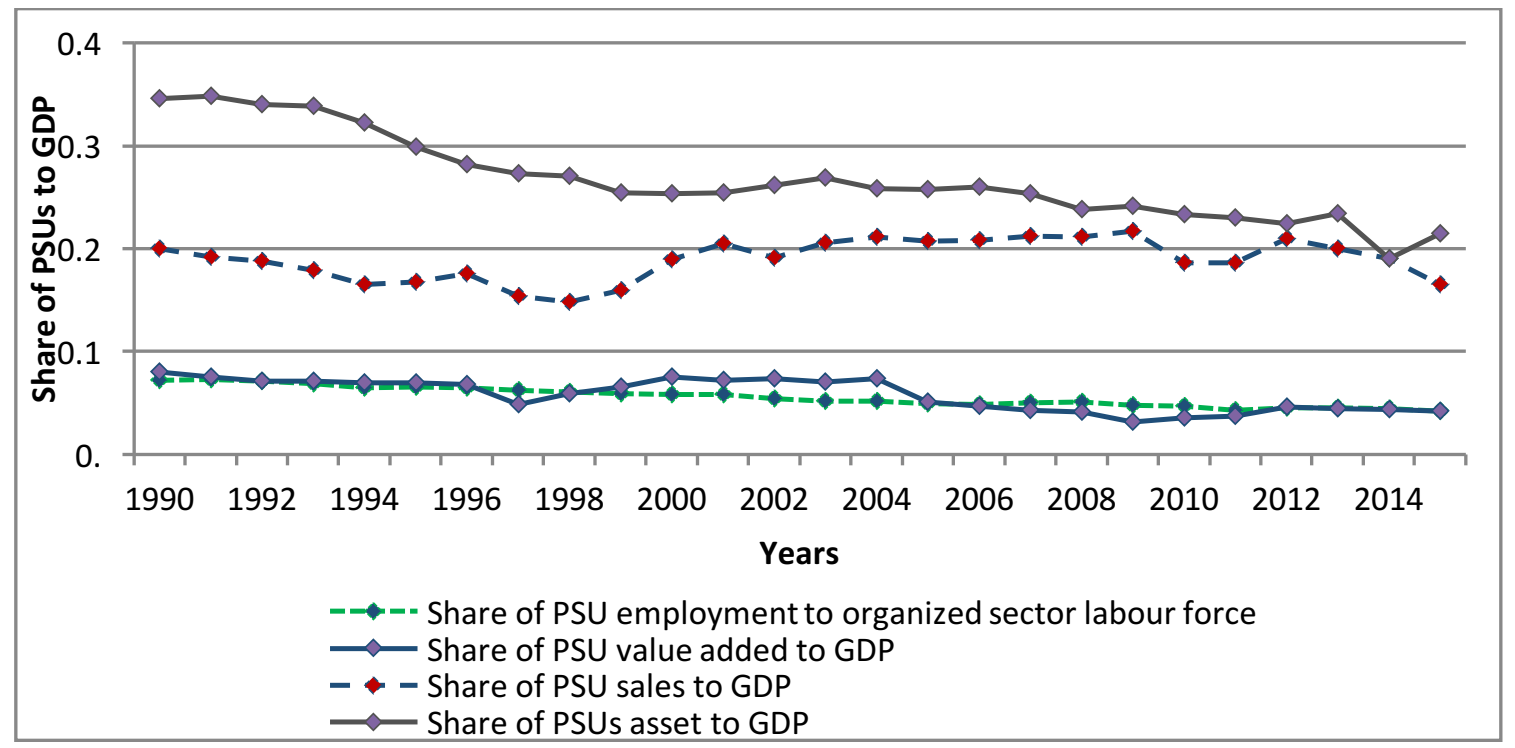

Note. Source: Public Enterprise Survey, 1988-89 to 2014-15.

Figure 1. Value added, sales, and employment in PSUs (1990-2015).

The economic reforms of 1991 dismantled the "license-raj" but left the PSUs more or less intact. Vigorous efforts were made to try and improve their performance through performance contracts called Memorandums of Understanding (MoUs) with some success as the number of loss makers declined. But yet, with still a third of the PSUs making substantial losses.

A partially successful attempt made under the NDA-1 government from 1999-2004 to initiate the dismantling of this legacy with strategic disinvestment (privatization) met with considerable opposition from vest- 
ed interests and labour unions. Subsequent UPA governments have tried to further improve the performance of these companies through better performance contracts and bringing more PSUs into the Ratna classification. The number of MoUs increased rapidly in the early 1990s from 4 in 1988-89 to over 100 by 1994-95. A second big jump came in the late 2000s and the number of MoUs jumped to 197 by 2009-10 and to 215 by $2015-16$, with only 20 PSUs now remaining without performance contracts (Figure 2).

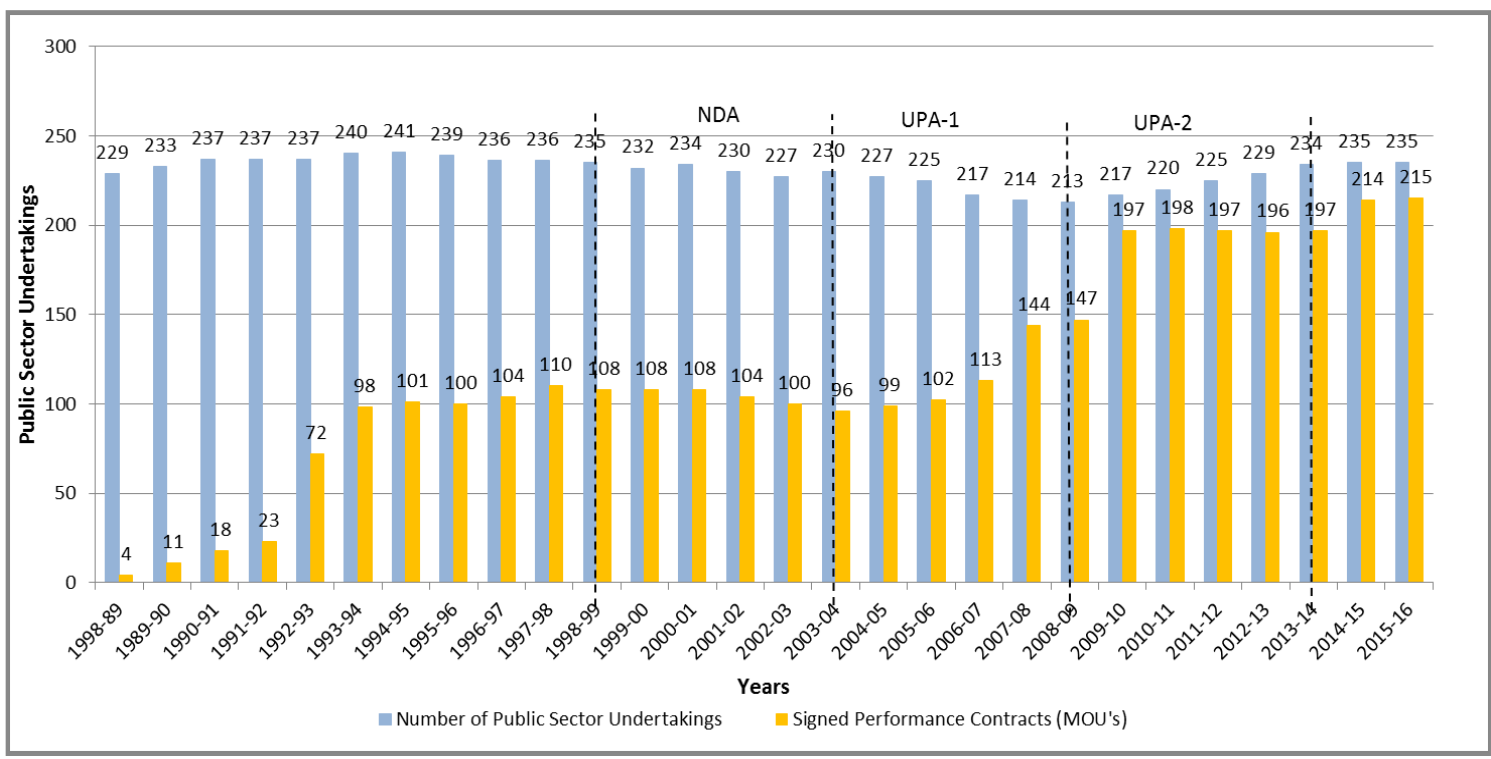

Note. Source: Public Enterprise Survey, 1988-89 to 2014-15.

Figure 2. Growth of PSUs and performance contracts (MoUs).

The Department of Disinvestment was created in 1999 and the objective of disinvestment under it was not only to raise revenue but also to improve efficiency. Over 30 companies were either fully privatized or $50 \%$ of their stock divested ${ }^{1}$, including one of India's most successful privatization initiatives - the sale of Maruti to Suzuki was completed during this period. But, the initiatives were internally opposed within the NDA government and the bureaucracy as the control over PSUs would have meant jobs, patronage and corruption in PSU contracts. What is surprising is that while the NDA government was aggressively pursuing privatization, some new PSUs were also created.

The UPA-1 government which came to power in 2004, backed by the communists, did not aim to privatize PSUs, although a few were shut down. UPA-2 brought back disinvestment with the intent to raise revenue, and the share of private equity in total equity in all PSUs combined jumped from around 4\% in 2008-09 to over 9\% by 2013-14 (Figure 3). Over one-third of the PSUs had some private equity in them.

\footnotetext{
${ }^{1}$ Bombay Stock Exchange Disinvestments Database, March 2015.
} 


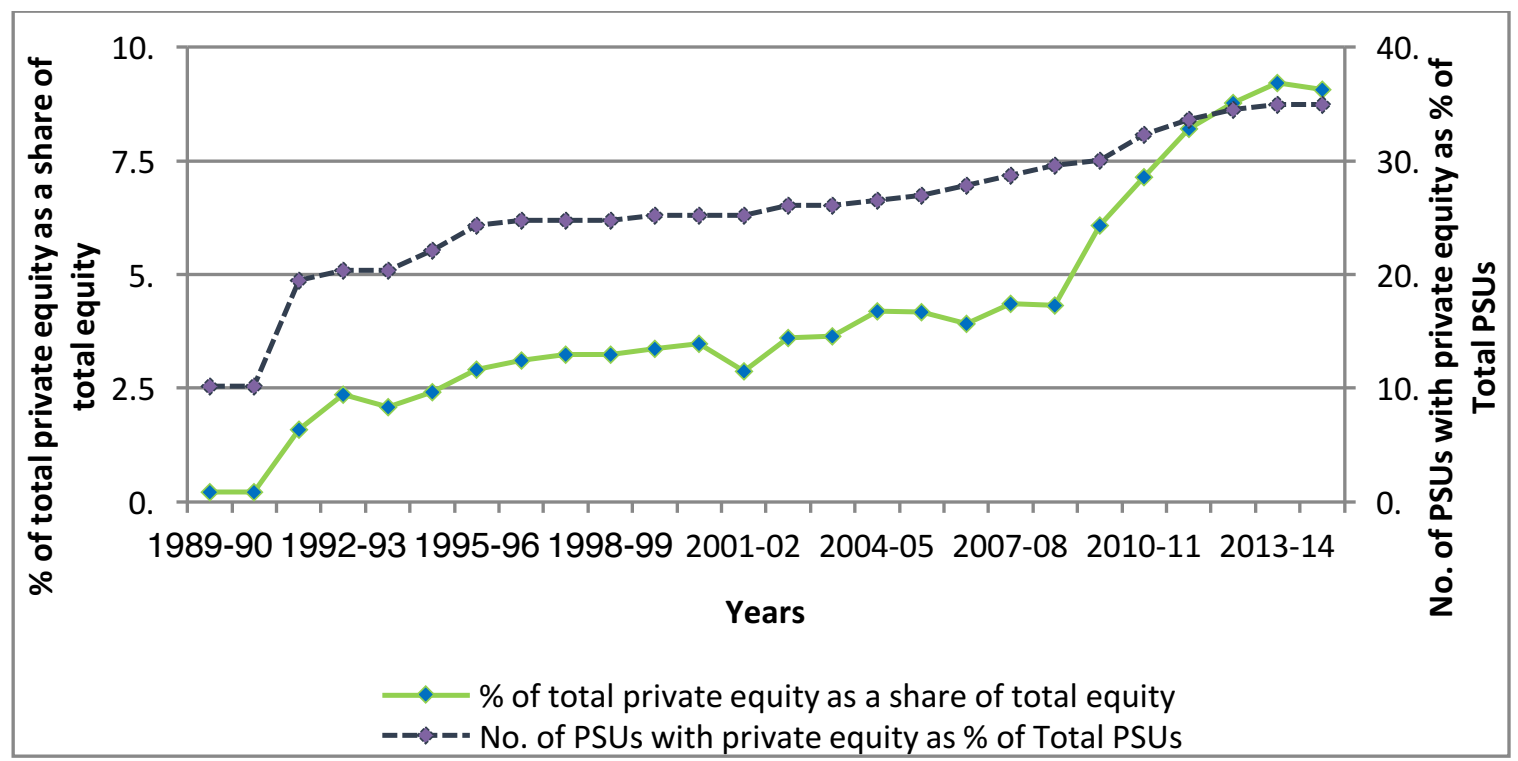

Note. Source: Public Enterprise Survey, 1989-90 to 2014-15.

Figure 3. Progress on disinvestment (partial privatization) 1990-2015.

The UPA 1 government also encouraged the restructuring of State-owned firms by creating the Bureau for Restructuring of Public Firms. A National Investment Fund was also created to collect disinvestment receipts, with the idea that it would be strategically deployed rather than used as part of budget receipts. Following fiscal pressures after the 2009 crisis, the criterion was gradually relaxed until the fund, for all practical purposes, became part of the budget. With the NDA government coming to power in 2014, there was an expectation that the disinvestment, pursued quite aggressively by NDA-1, would be taken up again and while not much has happened in the first two years so far there are signals that more effort will be made in the remainder of its term - especially with the decision to sell Air India.

Almost half of the PSUs were making losses in the 1990s, but with the period of high growth from 2002-3 onwards, the number of loss-making PSUs declined to about a quarter (Figure 4). But since then and especially once growth slowed down after 2012, the share of loss makers has increased again to almost onethird of the total. Profitability of the PSUs, measured here by profits over total sales, has also increased from an abysmal level of $2 \%$ in $1990-91$ to around $3 \%$ by $2000-01$, then peaked at almost $9 \%$ between 2003-4 and 2006-7 and has since fallen to between 5-6\%. How much of the improved performance is due to MoUs and how much is due to partial privatization will be explored further in the later sections of the paper. We will also explore whether there are differences in performance due to hard budget constraints as well as the degree of competitiveness in the industry in which the PSU is operating. 


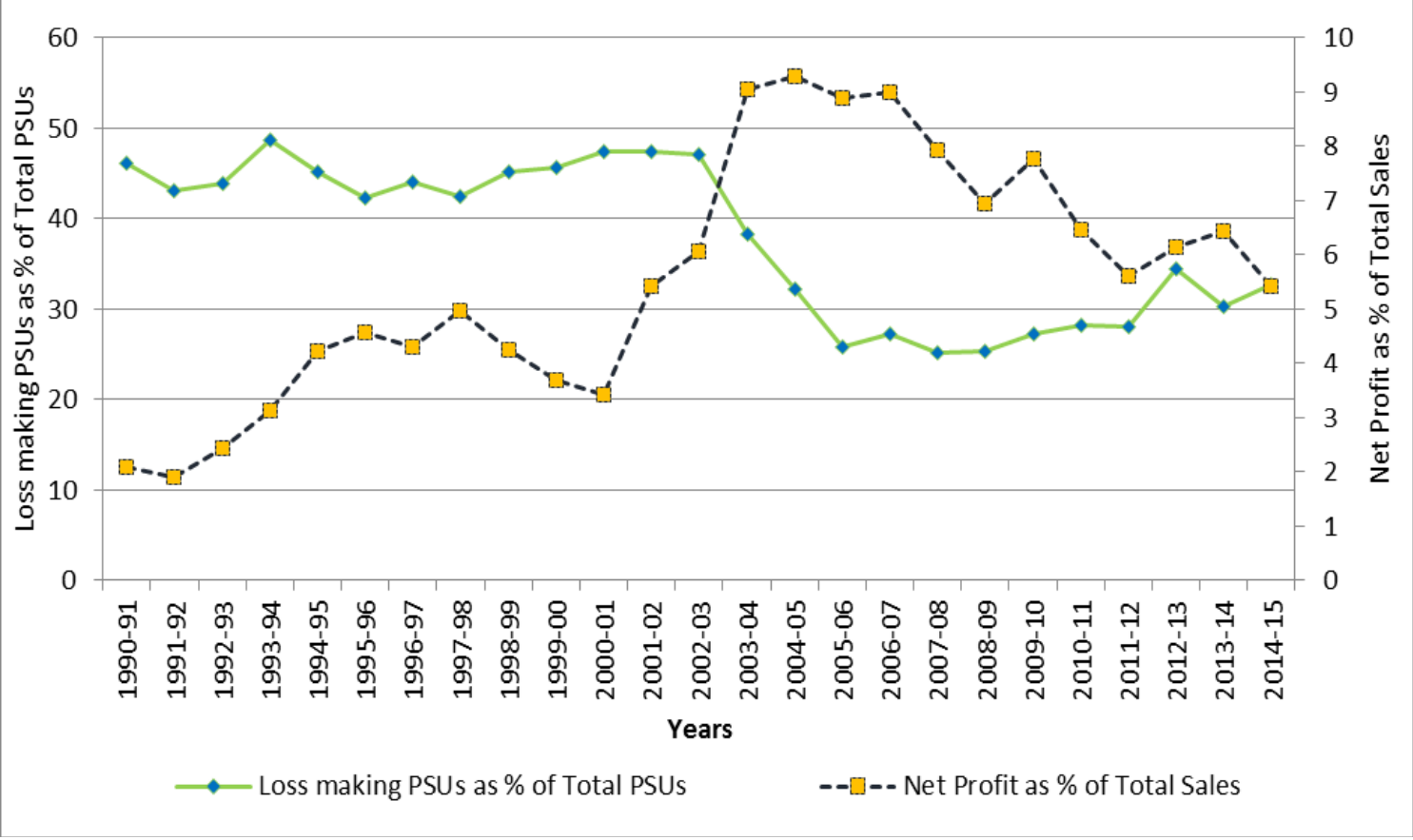

Note. Source: Public Enterprise Survey, 1989-90 to 2014-15.

Figure 4. Trends in profits and losses in the Indian PSUs (1990-91 to 2014-15).

\section{Earlier studies on PSU performance in India and the proposed approach}

There are a vast number of studies on privatization around the world with mixed results. Many of them show that privatization improves labour productivity and even profitability but not necessarily overall efficiency and productivity. A comprehensive survey (Megginson \& Netter, 2001) of this literature concluded that divested (fully and partially privatized) firms almost always become more profitable and more efficient. An OECD survey soon thereafter also arrived at the same conclusion. Subsequent surveys (Muhlenkamp, 2013) have questioned these findings and shown that the previous survey suffered from flaws. It questions whether privatization leads to greater efficiency and argues that public and private sector firms perform the same when subject to competition and better regulation. Few authors have argued that many of the studies have methodological flaws because the gains from privatization may be due to selection bias since better performing PSUs may be privatized first. The most recent survey by UNDP's Global Centre for Public Service Excellence (GSCPE, 2017) shows that privatization is likely to lead to positive results in markets with greater competition and better regulation. These results are more likely in developed countries but not so in middle income and developing economies, where the results of privatization are more mixed.

There are a large number of studies that discuss the performance of PSUs in the Indian context. But very few of these use rigorous techniques and are therefore largely descriptive (Arun \& Nixson, 2000; Mathur, 2010; Nagaraj, 2005; and Trivedi, 1990). Some of the most prominent rigorous studies (e.g., Gupta, 2006, 2011) showed that disinvestment (even the sale of minority shares) had a positive effect on PSU financial performance, ostensibly because new owners injected greater commercial drive, which helped improve 
profitability. But this result has been challenged by recent studies as it did not factor in the effect of performance contracts - MoUs. More recent studies (Gunasekar \& Sarkar, 2014) showed that when PSUs with and without MoUs are considered, much of the financial performance improvement - earlier attributed to privatization - is due to the performance effect of MoUs. The positive effect of privatization disappears once the MOU performance effect is taken into account. So, a policy of selling a minority stake (up to $49 \%$ ) as a disinvestment measure is unlikely to have any positive effect on financial performance.

In another recent paper, Jain (2016) used technical efficiency as the performance variable, instead of financial rates of return. She applied a stochastic frontier analysis technique to generate technical efficiency by industry and by firm and then examined the impact of disinvestment and the ideology of the state government in which the enterprise is located as well as whether the state government belongs to a political party that is different from the central government. The results indicated that disinvestment, even partial disinvestment, has a strong positive effect on firm performance. The political ideology of the state government as well as whether the state government and the central government belong to different parties has a significant effect on performance. Her results are, however, dependent on the credibility of the method used to calculate technical efficiency.

In a previous paper, Chhibber and Gupta (2017) analyzed the performance of India's 235 PSUs using firmlevel data over the period 1990-2015 from the Public Enterprise Survey (time series panel data set); the authors looked into the factors that explain financial performance - return on capital (ROC) and return on assets (ROA) of these PSUs. The results showed that MoUs had a positive impact on PSU performance by increasing their return on capital (ROC). This result holds mainly for the non-service sector (manufacturing, mining) but less so for service sector firms. In the case of service sector firms, partial privatization (share sales) had a positive impact on performance, making them ideal candidates for more aggressive disinvestment. The results also showed that larger PSUs - Maharatnas - appear to perform better on financial indicators than smaller PSUs and even better than private firms of similar size.

The present paper shifts from using financial rates of return which was used in the previous paper by Chhibber and Gupta (2017) to study measures of productivity in the PSUs. The paper uses value added per employee (VAE) as a measure of labour productivity. In addition, it also uses value added per assets (VAA) and value added per capital (VAC) as measures of efficient use of assets and capital and the turnover ratio measured by net sales to assets (NSA) as a measure of operational efficiency.

NSE and VAE have increased five-fold and four-fold, respectively, between 1990 and 2015 (Figure 5). On an annual average basis this translates to a $2.0 \%$ per annum for VAE against overall labour productivity growth of $5.2 \%$ for the labour force as a whole of the Indian economy. The increase in VAE was very rapid initially increasing from INR 400 per employee per hour in 1989-90 prices to INR 1600/- in 2003-04, fell sharply after that before recovering back to INR 1600/- per employee by 2014-15. Labour productivity in PSUs increased considerably slower than average labour productivity growth of around $5.2 \%$ for the economy as a whole (including low productivity sector such as agriculture) over the same period.

Value Added per asset has remained around 0.2 over the entire period 1990 to 2015 (Figure 6). It went up to 0.3 in 2003-04 but since then fell back to settle at 0.2. Value added per unit of capital has remained around 0.5 in 1990 and again at the end of the period 2015 but in between fluctuated considerably rising to 0.7 in 2003-04, falling to 0.2 in 2008-09 and then rising again after that. Net sales per asset (NSA) has increased from around 0.5 to 0.8 over the entire period 1990-2015. 


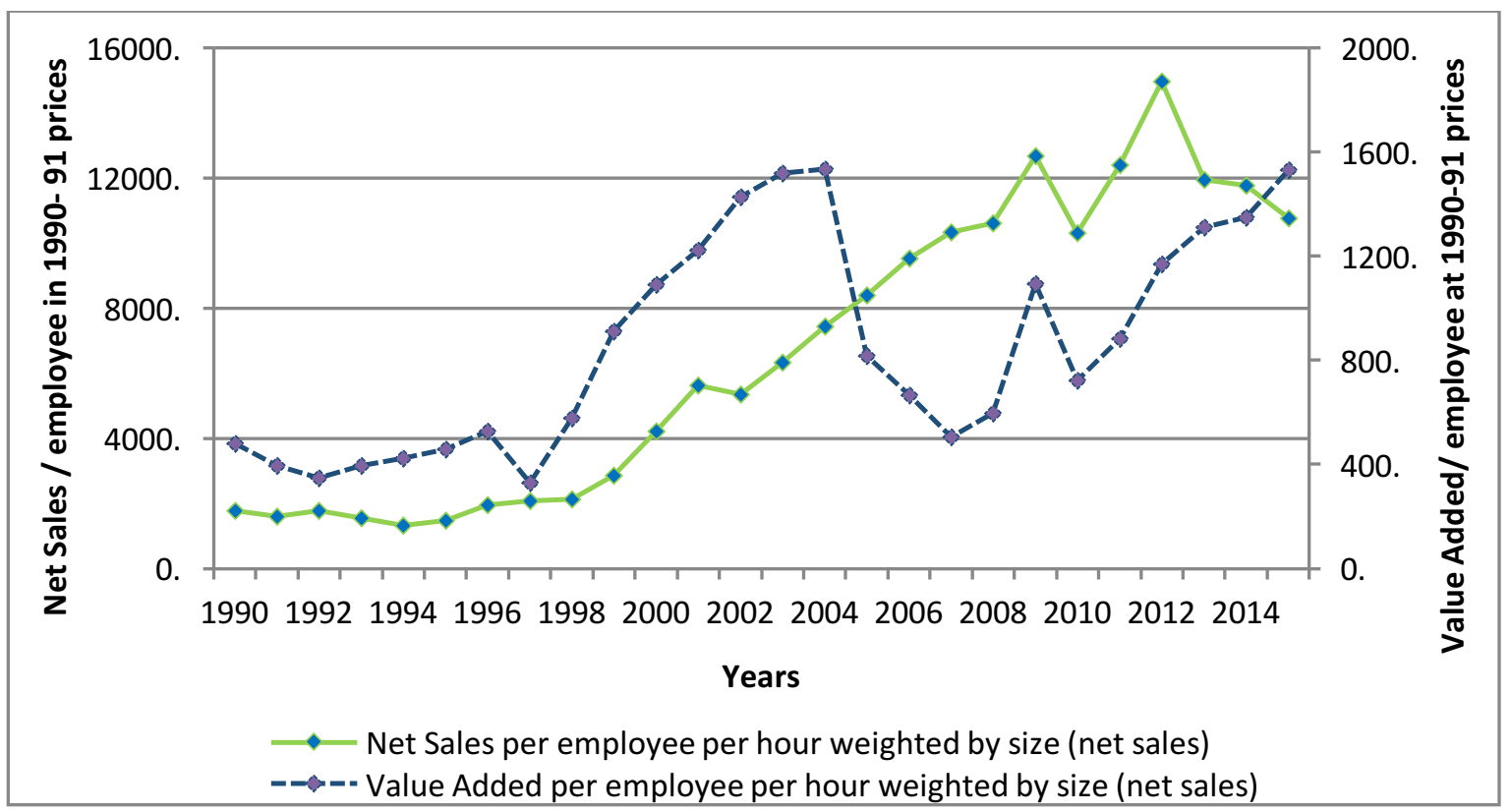

Note. Source: Public Enterprise Survey, 1989-90 to 2014-15.

Figure 5. Net sales and value added per employee in PSUs (1990-2015).

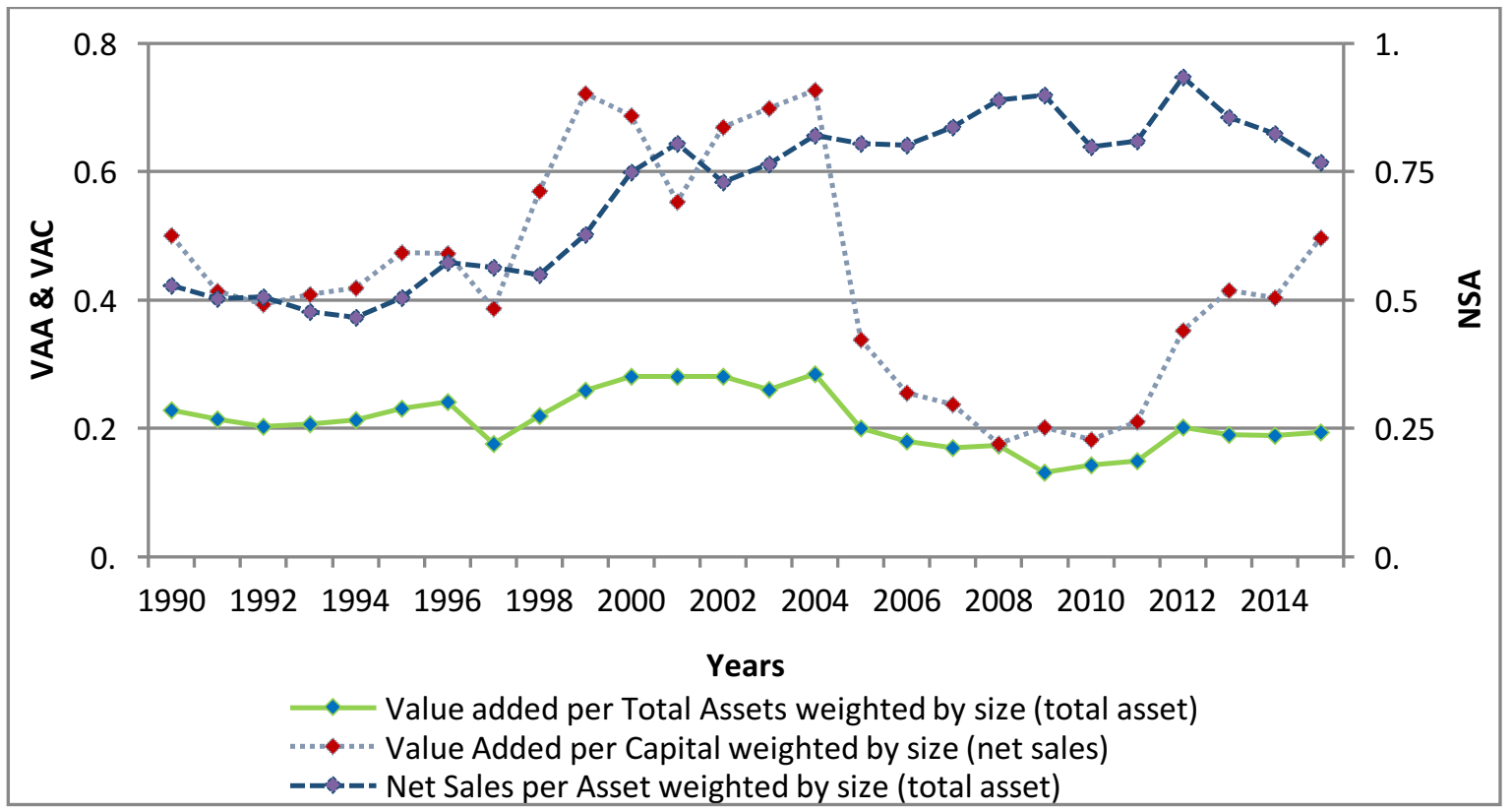

Note. Source: Public Enterprise Survey, 1989-90 to 2014-15

Figure 6. Value added per capital and per asset and net sales per asset (1990-2015). 


\section{The Model}

The nature of the industry, the size of the PSU, how well the economy is doing and other factors such as a hard budget constraint and the performance contracts can affect the performance of the PSUs. Some PSUs have soft budget constraints per se, some are given soft loans under various dispensations which allow them to have a soft budget as these loans are frequently rolled over. PSUs that are more export-oriented may also have better performance as they face greater external competition as against those that sell in a more protected domestic market - although lately, India has become more open so even PSUs selling largely into the domestic market face higher competition from imports.

For a better understanding of the effect of various factors on PSU productivity performance, the paper estimates a model over the period 1990 - 2015 using panel data assembled through the Public Enterprise Surveys which each PSU is required to file every year.

The model estimated for this paper is as follows:

$Y_{i t}=\alpha_{G}+\eta_{I}+\beta, X_{i t}+\eta^{\prime} P_{i t}+\gamma^{\prime} Z_{i t}+\varepsilon_{i t}$

where:

$Y_{i t}=$ represents the productivity performance variable, VAE, VAA, VAC for firm ' $i$ ' at time ' $t$ ';

$\alpha_{\mathrm{G}}=$ represents the group effects for Type-1, Type-2, and Type-3 PSUs;

$\eta_{I}=$ represents industry fixed effects;

$\mathrm{X}_{\mathrm{it}}=$ represents the variables for showing before and after effect of a performance contract MOU and partial privatization (disinvestment);

$\mathrm{P}_{\mathrm{it}}=$ represents the preparation effects - the actions taken to qualify for an MOU and disinvestments;

$Z_{i t}=$ represents the control variables;

$\varepsilon_{\mathrm{it}}=$ represents the error term.

Type-1 includes firms which neither have management autonomy nor are partially privatized, Type-2 includes firms which signed MoU with the government, and Type-3 includes firms which got partially privatized and signed MoU.

\section{Control Variables:}

SOFTLN = Ratio of loans borrowed by PSU from the central government to total loans borrowed, lagged by one year;

LASSET $=\log$ of total assets, which is a size effect;

EXINT $=$ Ratio of exports to total sales; 
DEPINT $=$ Ratio of depreciation expenditure to total sales;

$\mathrm{GRGDP}_{\text {constant price }}=$ Growth Rate of GDP at constant prices;

Industry effects = Industry dummies, one dummy for each of the 22 industry groups, taking the value of 1 for a particular industry and zero otherwise;

$\alpha_{2}=$ Dummy variable that takes the value of 1 for Type-2 PSUs and zero otherwise;

$\alpha_{3}=$ Dummy variable that takes the value of 1 for Type-3 PSUs and zero otherwise.

These are included to control for selection bias as the first of these dummies measure the average difference between firms with no MoU or disinvestment and the second captures the difference between firms with MoU but no disinvestment with those that had disinvestment.

\section{Performance Contract Variables:}

$\mathrm{MoU}=$ Dummy variable that takes the value of 1 in period ' $t+1$ ' if the firms had signed an MoU in year ' $t$ '; and the value of zero, otherwise;

mouprep0 = Dummy variable that takes the value of 1 for the year PSU signed an MoU and zero otherwise; mouprep1 = Dummy variable that takes the value of 1 for year ' $t-1$ ' if the firms signed an MoU in year ' $t$ ' and zero otherwise;

mouprep2 = Dummy variable that takes the value of 1 for year ' $t-2$ ' if the firms signed an MoU in year ' $t$ ' and zero otherwise;

mouprep3 = Dummy variable that takes the value of 1 for year ' $t$-3' if the firms signed an MoU in year ' $t$ ' and zero otherwise.

\section{Partial Privatization Variables:}

ppvt_dummy $=$ Dummy variable that takes the value of 1 for PSU in time ' $t$ ' and thereafter if the firm gets partially privatized in year ' $t$ ' and zero otherwise;

ppvt_shr $=$ Share of private equity to the PSU total equity;

ppvt_prep1 = Dummy variable that takes the value of 1 for year ' $t-1$ ' if the PSU became partially privatized in year ' $t$ ' and zero otherwise;

ppvt_prep 2 = Dummy variable that takes the value of 1 for year ' $t-2$ ' if the PSU became partially privatized in year ' $t$ ' and zero otherwise;

ppvt_prep3 = Dummy variable that takes the value of 1 for year ' $t-3$ ' if the PSU became partially privatized in year ' $t$ ' and zero otherwise; 
Table 1 shows the sample description of the sub-samples of PSUs to study the differential impact of 'MoU signed with the government'.

Initially, we use S1, where we include all the observations of type- 1 and type- 2 and type- 3 preprivatization:

$\mathrm{Y}_{\mathrm{it}}=\alpha_{2}+\alpha_{3}+\eta_{\mathrm{I}}+\beta_{1} \mathrm{MoU}_{\mathrm{it}}+\eta^{\prime} \mathrm{P}_{\mathrm{it}}+\gamma^{\prime} \mathrm{Z}_{\mathrm{it}}+\varepsilon_{\mathrm{it}}$.

The second estimation is done using S2, which excludes type-1 PSU, focusing only on the firms which have an MoU and had share sales. It consists of type- 2 and type-3 observations pre-privatization only:

$\mathrm{Y}_{\mathrm{it}}=\alpha_{3}+\eta_{\mathrm{I}}+\beta_{1} \mathrm{MoU}_{\mathrm{it}}+\eta^{\prime} \mathrm{P}_{\mathrm{it}}+\gamma^{\prime} \mathrm{Z}_{\mathrm{it}}+\varepsilon_{\mathrm{it}}$.

Table 1

Description of Sample Used in the Analysis by Type of PSUs

\begin{tabular}{|c|c|c|c|c|c|c|}
\hline & \multicolumn{6}{|c|}{ Sample Observations } \\
\hline & Type-1 & \multicolumn{2}{|c|}{ Type-2 } & \multicolumn{3}{c|}{ Type-3 } \\
\hline $\begin{array}{c}\text { Sample } \\
\text { Type }\end{array}$ & No Reform & Pre-MOU & Post-MOU & Pre-MOU & $\begin{array}{c}\text { Post MOU- } \\
\text { Pre-PPVT }\end{array}$ & Post-PPVT \\
& Regime 1 & Regime 1 & Regime 2 & Regime 1 & Regime 2 & Regime 3 \\
\hline S1 & $\sqrt{ }$ & $\sqrt{ }$ & $\sqrt{ }$ & $\sqrt{ }$ & $\sqrt{ }$ & - \\
\hline S2 & - & $\sqrt{ }$ & $\sqrt{ }$ & $\sqrt{ }$ & $\sqrt{ }$ & - \\
\hline S3 & - & $\sqrt{ }$ & $\sqrt{ }$ & - & - & - \\
\hline S4 & $\sqrt{ }$ & $\sqrt{ }$ & $\sqrt{ }$ & $\sqrt{ }$ & $\sqrt{ }$ & $\sqrt{ }$ \\
\hline S5 & - & $\sqrt{ }$ & $\sqrt{ }$ & $\sqrt{ }$ & $\sqrt{ }$ & $\sqrt{ }$ \\
\hline S6 & - & - & - & $\sqrt{ }$ & $\sqrt{ }$ & $\sqrt{ }$ \\
\hline
\end{tabular}

The third estimation is done using S3 by taking type-2 firms only, i.e., those with MoUs, but excludes those that had share sales:

$\mathrm{Y}_{\mathrm{it}}=\eta_{\mathrm{I}}+\beta_{1} \mathrm{MOU}_{\mathrm{it}}+\eta^{\prime} \mathrm{P}_{\mathrm{it}}+\gamma^{\prime} \mathrm{Z}_{\mathrm{it}}+\varepsilon_{\mathrm{it}}$.

The fourth estimation is done using S4 by taking all the three types, type-1, type-2, and type- 3 , to show the impact of partial privatization on the entire sample of firm-year observations. Given that all partially privatized PSUs were also under MoU, the coefficient of the partial privatization variable that is PPVT_DUMMY and PPVT_SHR captures its incremental effect over and above the MoU.

$\mathrm{Y}_{\mathrm{it}}=\alpha_{2}+\alpha_{3}+\eta_{\mathrm{I}}+\beta_{1} \mathrm{MoU}_{\mathrm{it}}+\beta_{2}$ PPVT_DUMMY/PPVT_SHR $\mathrm{it}_{\mathrm{it}}+\eta^{\prime} \mathrm{P}_{\mathrm{it}}+\gamma^{\prime} \mathrm{Z}_{\mathrm{it}}+\varepsilon_{\mathrm{it}}$ 
The fifth estimation is done using S5, which excludes type-1 PSUs, focusing only on the firms which have an $\mathrm{MoU}$ and had share sales. It consists of type- 2 and type- 3 observations, including post-privatization of type-3.

$\mathrm{Y}_{\mathrm{it}}=\alpha_{3}+\eta_{\mathrm{I}}+\beta_{1} \mathrm{MOU}_{\mathrm{it}}+\beta_{2} \mathrm{PPVT} \_\mathrm{DUMMY} / \mathrm{PPVT} \mathrm{SHR}_{\mathrm{it}}+\eta^{\prime} \mathrm{P}_{\mathrm{it}}+\gamma^{\prime} \mathrm{Z}_{\mathrm{it}}+\varepsilon_{\mathrm{it}}$

The sixth estimation is done using S6 and is similar to S2, and is conducted before and after study of only type-3 PSUs, those who signed the MoU and partially privatized, to compare their performance before and after partial privatization.

$\mathrm{Y}_{\mathrm{it}}=\eta_{\mathrm{I}}+\beta_{1} \mathrm{MOU}_{\mathrm{it}}+\beta_{2} \mathrm{PPVT} \_\mathrm{DUMMY} / \mathrm{PPVT} \_\mathrm{SHR}_{\mathrm{it}}+\eta^{\prime} \mathrm{P}_{\mathrm{it}}+\gamma^{\prime} \mathrm{Z}_{\mathrm{it}}+\varepsilon_{\mathrm{it}}$

\section{Empirical Findings and Implications}

Using the latest PSU survey data, we have estimated the equations (1), (2), and (3) for the period 19902015 with value added per employee (VAE) as the dependent variable.

Value Added per Employee (VAE) is often used as a measure of labour productivity. Performance contract MoU has no significant effect on VAE (Table 2a). Firm size LASSET has a significant positive effect on VAE. Soft loans have a positive effect on labour productivity - presumably as these funds are used to buy new equipment and/or for labour training.

Table $2 \mathrm{a}$

Regression for Value Added per Employee (VAE) MOU Effect (1990-2015)

\begin{tabular}{|c|c|c|c|c|c|c|}
\hline Variables & Sub-San & nple S1 & Sub-Sar & nple S2 & Sub-San & nple S3 \\
\hline & (i) & (ii) & (iii) & (iv) & (v) & (vi) \\
\hline Intercept & $\mid-0.2258045 * * *$ & $-0.2223916 * * *$ & $\mid-0.2585025 * * *$ & $-0.2460657 * * *$ & $-0.2363382 * * *$ & $-0.2247423 * * *$ \\
\hline mou_prep0 & & $-0.0278763 * *$ & & $-0.0260053 *$ & & -0.022787 \\
\hline mou_prep1 & & -0.0133997 & & -0.0116697 & & -0.0101831 \\
\hline mou_prep2 & & -0.0262621 & & -0.0244716 & & -0.019113 \\
\hline mou_prep3 & & $-0.0405593 * *$ & & $-0.0391663 *$ & & -0.0267375 \\
\hline MOU & -0.0103466 & -0.0152996 & -0.0101205 & -0.0146697 & -0.0128594 & -0.0159353 \\
\hline SOFTLN & 0.0164172 & 0.0168321 & $0.0211019 *$ & $0.0212305 *$ & $0.0257695^{* *}$ & $0.0252534^{* *}$ \\
\hline LASSET & $0.1444896 * * *$ & $0.1398684^{* * *}$ & $0.1538821 * * *$ & $0.1490752 * * *$ & $0.1452213^{* * *}$ & $0.1407979 * * *$ \\
\hline EXINT & -0.000213 & -0.0002221 & -0.0051774 & -0.0052701 & -0.0012675 & -0.0013905 \\
\hline DEPINT & 0.0000615 & 0.0000753 & -0.0080143 & -0.0073881 & -0.0067736 & -0.0061886 \\
\hline GRGDP constant price & -0.0008827 & -0.0004893 & -0.0011652 & -0.0007507 & -0.0022307 & -0.0018954 \\
\hline$\alpha 2$ & -0.0131572 & -0.0040889 & NA & NA & NA & NA \\
\hline$\alpha 3$ & $-0.13802 * * *$ & $-0.1220562 * *$ & $-0.1279139 * * *$ & $-0.1211764 * * *$ & $\mathrm{NA}$ & NA \\
\hline industry effects & Included & Included & Included & Included & Included & Included \\
\hline Adj. R-sqr & 0.342 & 0.346 & 0.3453 & 0.349 & 0.3748 & 0.3786 \\
\hline No. of Observations & 2536 & 2536 & 2401 & 2401 & 2121 & 2121 \\
\hline
\end{tabular}

Note. Source: Author's calculation using data from Public Enterprise Survey (1990-2015).

$*$ Significance at $10 \%$ level $* *$ Significance at $5 \%$ level $* * *$ Significance at $1 \%$ level. 
In contrast to performance contracts disinvestment - whether measured by privatization dummy (ppvt_dummy) or by the private share in equity - it has a strong and very significant positive effect on VAE (Tables $2 b$ and $2 c$ ). In fact, when a privatization dummy is used, the benefits of a decision to divest starts three years prior to the actual divestment. Firm size also has a strong positive effect on value added per employee. In the case of S3 firms, export orientation has a negative effect on VAE.

The coefficients of the dummy variable $\alpha_{2}$ for Type 2 firms which signed an MOU are negative but insignificant, which suggests Type 1 firms have on average the same VAE compared to Type 2 firms. The coefficient for the dummy variable $\alpha_{3}$, which controls for group effects of firms that had some privatization, is negative and highly significant. This shows that on average VAE is lower for Type 3 firms when compared to Type 2 firms. These variables were introduced to remove selection bias.

The results for value added per employee (VAE) as a measure of labour productivity suggest that the introduction of performance contracts (MoUs) has no significant effect on them. However, disinvestment has a very significant and positive impact on them. This result is not so surprising as many studies found that privatization increases labour productivity, as firms retrench labour and invest in capital after privatization. In the case of Indian PSUs, retrenchment is not so easy, so the result is largely due to more efficient use of labour through restructuring, also possibly due to new investment in equipment from the proceeds of the disinvestment: some of which are retained by the PSU and some passed back to the budget.

Table $2 b$

Regression for Value Added per Employee (VAE) Disinvestment Effect (1990-2015)

\begin{tabular}{|c|c|c|c|c|c|c|}
\hline \multirow[t]{2}{*}{ Variables } & \multicolumn{2}{|c|}{ Sub-Sample S4 } & \multicolumn{2}{|c|}{ Sub-Sample S5 } & \multicolumn{2}{|c|}{ Sub-Sample S6 } \\
\hline & (i) & (ii) & (iii) & (iv) & (v) & (vi) \\
\hline Intercept & $-0.2410661 * * *$ & $-0.2303463 * * *$ & $-0.286218 * * *$ & $-0.2718267^{* * *}$ & $-0.8713268 * * *$ & $-0.8644863 * * *$ \\
\hline ppvt_dummy & $0.1594198 * * *$ & $0.2739901 * * *$ & $0.1567953 * * *$ & $0.269816 * * *$ & $0.0926618 * * *$ & $0.1735557 * * *$ \\
\hline ppvt_prep1 & & $0.1890245^{* * *}$ & & $0.1863496 * * *$ & & $0.1275967 * * *$ \\
\hline ppvt_prep2 & & $0.1857151 * * *$ & & $0.1833557 * * *$ & & $0.1234164 * * *$ \\
\hline ppvt_prep3 & & $0.0734235 * * *$ & & $0.0717535 *$ & & 0.0123478 \\
\hline mou_prepo & -0.019572 & -0.0229785 & -0.0186553 & -0.0219736 & 0.0108952 & -0.0033748 \\
\hline mou_prep1 & 0.0023797 & 0.0003994 & 0.0039184 & 0.0020352 & 0.0710983 & 0.066326 \\
\hline mou_prep2 & -0.015233 & -0.0157661 & -0.0128534 & -0.013406 & -0.0086199 & -0.0120891 \\
\hline mou_prep3 & -0.032179 & -0.0274962 & -0.030239 & -0.0256122 & -0.0845523 & -0.0612194 \\
\hline MOU & -0.0140878 & -0.0149253 & -0.0137239 & -0.0144676 & -0.0016068 & -0.0044511 \\
\hline SOFTLN & 0.0138858 & 0.0137378 & 0.0182893 & 0.0181099 & -0.0283872 & -0.0309465 \\
\hline LASSET & $0.161761 * * *$ & $0.1563224 * * *$ & $0.1725626 * * *$ & $0.1669571 * * *$ & $0.3551607 * * *$ & $0.3327858 * * *$ \\
\hline EXINT & -0.0003078 & -0.0002872 & $-0.0108614 *$ & -0.009557 & $-0.2291217 * * *$ & $-0.206119 * * *$ \\
\hline DEPINT & -0.0002997 & -0.0002538 & -0.0009594 & -0.0008678 & 0.0002163 & 0.0002107 \\
\hline GRGDP constant price & -0.0020222 & -0.002253 & -0.0024062 & $-0.0026422 *$ & -0.0054282 & -0.0060932 \\
\hline$\alpha 2$ & -0.0224055 & -0.0191119 & NA & NA & NA & NA \\
\hline$\alpha 3$ & $-0.2238862 * * *$ & $-0.3130697 * * *$ & $-0.2024044 * * *$ & $-0.2930852 * * *$ & NA & NA \\
\hline industry effects & Included & Included & Included & Included & Included & Included \\
\hline Adj. R-sqr & 0.3542 & 0.3507 & 0.355 & 0.3519 & 0.3898 & 0.386 \\
\hline No. of Observations & 3044 & 3044 & 2909 & 2909 & 826 & 826 \\
\hline
\end{tabular}

Note. Source: Author's calculation using data from Public Enterprise Survey (1990-2015).

*Significance at $10 \%$ level; **Significance at $5 \%$ level; *** Significance at $1 \%$ level. 
Table 2c

Regression for Value Added per Employee (VAE) Private Equity Effect (1990-2015)

\begin{tabular}{|c|c|c|c|c|c|c|}
\hline Variables & \multicolumn{2}{|c|}{ Sub-Sample S4 } & \multicolumn{2}{|c|}{ Sub-Sample S5 } & \multicolumn{2}{|c|}{ Sub-Sample S6 } \\
\hline & (i) & (ii) & (iii) & (iv) & (v) & (vi) \\
\hline Intercept & $-0.2291219 * * *$ & $-0.2270638 * * *$ & $-0.2809798 * * *$ & $-0.2787635 * * *$ & $-0.7803 * * *$ & $-0.7466797 * * *$ \\
\hline ppvt_shr & $0.4819101 * * *$ & $0.5057038 * * *$ & $0.4814733 * * *$ & $0.5066897 * * *$ & $0.4047398 * * *$ & $0.4886218 * * *$ \\
\hline ppvt_prep1 & & 0.0360848 & & 0.0368605 & & 0.0556799 \\
\hline ppvt_prep2 & & 0.0372015 & & 0.0380235 & & 0.059116 \\
\hline ppvt_prep3 & & -0.0426033 & & -0.0419697 & & -0.0443217 \\
\hline mou_prepo & $-0.0275489 *$ & $-0.0304743 * *$ & $-0.0264404 *$ & $-0.0293759 *$ & -0.0150768 & -0.0368187 \\
\hline mou_prep1 & -0.0074839 & -0.0084549 & -0.0057297 & -0.0067089 & 0.0299319 & 0.0157313 \\
\hline mou_prep2 & -0.0255762 & -0.0270358 & -0.0231265 & -0.0245941 & -0.0605596 & -0.0824371 \\
\hline mou_prep3 & -0.0360797 & $-0.0358677 \|$ & -0.0341664 & -0.0339175 & -0.1120478 & -0.1093088 \\
\hline $\mathrm{MOU}$ & -0.0187982 & -0.0193988 & -0.0182247 & -0.0188196 & -0.0140436 & -0.0198361 \\
\hline SOFTLN & 0.0133763 & 0.0123373 & 0.0168880 & 0.0157818 & -0.0283479 & -0.0322337 \\
\hline LASSET & $0.1588993 * * *$ & $0.1581833^{* * *}$ & $0.1689318 * * *$ & $0.1682546 * * *$ & $0.3295223 * * *$ & $0.3148682 * * *$ \\
\hline EXINT & -0.0003197 & -0.0003205 & $-0.0118556 *$ & $-0.0117549 * \|$ & $-0.2336744 * * *$ & $-0.2245043 * * *$ \\
\hline DEPINT & -0.0001433 & -0.0001116 & -0.0006297 & -0.0005641 & 0.0002479 & 0.0002953 \\
\hline GRGDP constant price & -0.0020436 & -0.0020895 & -0.0023879 & -0.0024376 & 0.0003644 & -0.0057559 \\
\hline$\alpha 2$ & -0.0306418 & -0.030413 & NA & $\mathrm{NA}$ & NA & NA \\
\hline$\alpha 3$ & $-0.1445915^{* * *}$ & $-0.1475657 * * *$ & $-0.115329 * * *$ & $-0.1186918 * * *$ & NA & NA \\
\hline industry effects & Included & Included & Included & Included & Included & Included \\
\hline Adj. R-sqr & 0.3692 & 0.3689 & 0.3686 & 0.3682 & 0.4049 & 0.4076 \\
\hline No. of Observations & 3037 & 3037| & 2903 & 2903 & 826 & 826 \\
\hline
\end{tabular}

Note. Source: Author's calculation using data from Public Enterprise Survey (1990-2015).

*Significance at $10 \%$ level; **Significance at 5\% level; *** Significance at $1 \%$ level

Having established that privatization improves labour productivity, we turn next to value added per capital VAC (a measure of the productive use of capital) and value added per assets VAA (a measure of the productive use of assets - which include land and other assets).

Table 3a shows that performance contracts MOU have no positive impact on value added per unit of capital (VAC). Disinvestment as measured by the privatization dummy in Tables $3 \mathrm{~b}$ and $3 \mathrm{c}$ has a very significant and positive impact on VAC, especially once the privatization preparation dummies are also introduced. But when private equity share is used as the disinvestment variable, it has no significant effect on VAC. 
Table $3 \mathrm{a}$

Regression for Value Added per Capital (VAC) MOU Effect (1990-2015)

\begin{tabular}{|c|c|c|c|c|c|c|}
\hline Variables & Sub-San & nple S1 & Sub-Sar & iple S2 & Sub-Sam & ple S3 \\
\hline & (i) & \begin{tabular}{|l|} 
(ii) \\
\end{tabular} & (iii) & (iv) & (v) & (vi) \\
\hline Intercept & $0.1696551 *$ & $0.1681746 *$ & $0.2940761 * * *$ & $0.2929685^{* * *}$ & $0.3002602 * * *$ & $0.2962975^{* * *}$ \\
\hline mou_prep0 & & -0.0037613 & & -0.0026975 & & 0.0033147 \\
\hline mou_prep1 & & 0.0033147 & & 0.0029524 & & 0.0104903 \\
\hline mou_prep2 & & 0.0154563 & & 0.0147798 & & 0.024276 \\
\hline mou_prep3 & & $-0.0516154 *$ & & $-0.0523843 *$ & & -0.0485762 \\
\hline MOU & -0.0127381 & -0.0132915 & -0.0128295 & -0.0133533 & -0.0128998 & -0.0122389 \\
\hline SOFTLN & 0.0074943 & 0.0082519 & 0.0060238 & 0.0068344 & 0.0028195 & 0.0034297 \\
\hline LASSET & $0.0283787 * *$ & $0.0284637 * *$ & $0.0271776 * *$ & $0.0272151^{* *}$ & $0.024462 *$ & $0.0254699 *$ \\
\hline EXINT & -0.0002233 & -0.0002255 & -0.0001624 & -0.0001643 & -0.0001616 & -0.00016 \\
\hline DEPINT & -0.0012406 & -0.0012429 & -0.0128936 & -0.0129855 & -0.0121612 & -0.0124492 \\
\hline GRGDP constant price & $-0.0059252 * * *$ & $-0.0057353 * * *$ & $-0.0056466 * *$ & $-0.005431 * *$ & $-0.0064354 * * *$ & $-0.0062863 * *$ \\
\hline$\alpha 2$ & $0.1235755 *$ & $0.1240748 *$ & NA & NA & $N A$ & NA \\
\hline$\alpha 3$ & $0.2710186 * * *$ & $0.2711567 * * *$ & $0.1544437 * * *$ & $0.1541158 * * *$ & $\mathrm{NA}$ & NA \\
\hline industry effects & Included & Included & Included & Included & Included & Included \\
\hline Adj. R- sqr & 0.1156 & 0.1159 & 0.1054 & 0.1058 & 0.1265 & 0.1271 \\
\hline No. of Observations & 2568 & 2568 & 2427 & 2427 & 2118 & 2118 \\
\hline
\end{tabular}

Note. Source: Author's calculation using data from Public Enterprise Survey (1990-2015).

*Significance at $10 \%$ level; **Significance at $5 \%$ level; *** Significance at $1 \%$ level.

Table $3 b$

Regression for Value Added per Capital (VAC) Disinvestment Effect (1990-2015)

\begin{tabular}{|c|c|c|c|c|c|c|}
\hline \multirow[t]{2}{*}{ Variables } & \multicolumn{2}{|c|}{ Sub-Sample S4 } & \multicolumn{2}{|c|}{ Sub-Sample S5 } & \multicolumn{2}{|c|}{ Sub-Sample S6 } \\
\hline & (i) & (ii) & (iii) & (iv) & (v) & (vi) \\
\hline Intercept & $0.2376224 * * *$ & $0.2423529 * * *$ & $0.4134831^{* * *}$ & $0.4200107^{* * *}$ & $0.8559085^{* * *}$ & $0.8603492^{* * *}$ \\
\hline ppvt_dummy & 0.0308124 & $0.0755507^{* *}$ & 0.0307148 & $0.074858 * *$ & $0.0622297 * *$ & $0.1099457 * * *$ \\
\hline ppvt_prep1 & & $0.0841775 *$ & & $0.0833077^{*}$ & & $0.0896645^{* *}$ \\
\hline ppvt_prep2 & & $0.0897114 * *$ & & $0.0884838^{* *}$ & & $0.0856125^{* *}$ \\
\hline ppvt_prep3 & & -0.0154792 & & -0.0163902 & & -0.0252378 \\
\hline mou_prepo & -0.006373 & -0.008942 & -0.0066344 & -0.0091981 & -0.0402375 & -0.0536965 \\
\hline mou_prep1 & -0.0003795 & -0.0007656 & -0.0008993 & -0.0012755 & -0.0543675 & -0.0565279 \\
\hline mou_prep2 & 0.00352 & 0.0030238 & 0.0031117 & 0.0026169 & -0.1241481 & $-0.1273287^{*}$ \\
\hline mou_prep3 & $-0.0577806^{*}$ & $-0.0556911^{*}$ & $-0.0580139 *$ & -0.0559515 & -0.1109501 & -0.0935009 \\
\hline $\mathrm{MOU}$ & -0.0157053 & -0.0158019 & -0.0159319 & -0.0160309 & -0.0518427 & -0.0539618 \\
\hline SOFTLN & -0.0107062 & -0.0100621 & -0.0143004 & -0.0136296 & -0.0239393 & -0.021393 \\
\hline LASSET & -0.0158306 & -0.0179637 & -0.0188504 & $-0.0210102 *$ & $-0.1127556 * * *$ & $-0.1247056^{* * *}$ \\
\hline EXINT & -0.0002636 & -0.0002649 & -0.000266 & -0.0002675 & $-0.2777707 * * *$ & $-0.2623968^{* * *}$ \\
\hline DEPINT & -0.0012329 & -0.0012008 & -0.0016217 & -0.0015605 & -0.0018209 & -0.0018118 \\
\hline GRGDP constant price & $-0.007601 * * *$ & $-0.0078021 * * * \|$ & $-0.0074548 * * *$ & $-0.00766 * * *$ & $-0.0096395^{* *}$ & $-0.0103441^{* * *}$ \\
\hline$\alpha 2$ & $0.1698472 * * *$ & $0.1715388 * * * \|$ & NA & NA & $\mathrm{NA}$ & NA \\
\hline$\alpha 3$ & $0.2819899 * * *$ & $0.2472693 * * *$ & $0.1152893 * *$ & 0.0793587 & NA & NA \\
\hline industry effects & Included & Included & Included & Included & Included & Included \\
\hline Adj. R- sqr & 0.134 & 0.1359 & 0.1232 & 0.1249 & 0.2966 & 0.2989 \\
\hline No. of Observations & 3104 & $3104 \|$ & 2963 & 2963 & 889 & 889 \\
\hline
\end{tabular}

Note. Source: Author's calculation using data from Public Enterprise Survey (1990-2015).

*Significance at $10 \%$ level $* *$ Significance at $5 \%$ level $* * *$ Significance at $1 \%$ level. 
MoUs have a negative effect on value added per assets (VAA) (Table 4a). Firm size LASSET and GDP growth also have a surprising negative effect on VAA. Larger firms have higher labour productivity - presumably since they use more capital but have lower value added per asset.

Disinvestment on the other hand has a very positive effect on VAA whether we measure disinvestment by a dummy variable for the year of disinvestment (ppvt_dummy) or whether we measure it by the share of private equity in total equity (ppvt_shr). The positive effect of disinvestment starts at least two years prior to the actual disinvestment as the variables ppvt_prior are positive and significant two years before the actual disinvestment. In this latter case, the effect of the performance contract MOU remains negative. Firm size and the capital intensity of the firm measured by the share of depreciation in total assets are also negative.

Bigger firms were seen to have higher returns on capital (ROC) and returns on assets (ROA) in an earlier research paper (Chhibber \& Gupta, 2017). Bigger firms also have higher labour productivity measured by VAE and NSPE. But on value added per asset (VAA), size has a negative effect, so bigger firms have lower value added per asset, the efficiency variable, although they have higher financial profitability measured by ROC or ROA.

Table 3c

Regression for Value Added per Capital (VAC) Private Equity Effect (1990-2015)

\begin{tabular}{|c|c|c|c|c|c|c|}
\hline Variables & \multicolumn{2}{|c|}{ Sub-Sample S4 } & \multicolumn{2}{|c|}{ Sub-Sample S5 } & \multicolumn{2}{|c|}{ Sub-Sample S6 } \\
\hline & (i) & (ii) & (iii) & (iv) & (v) & (vi) \\
\hline Intercept & $0.2498616^{* * *}$ & $0.2514431^{* * *}$ & $0.4388936 * * *$ & $0.4404136^{* * *}$ & $0.7696668^{* * *}$ & $0.7764581^{* * *}$ \\
\hline ppvt_shr & -0.1172725 & -0.1099987 & -0.1113951 & -0.1041454 & -0.0901177 & -0.0807926 \\
\hline ppvt_prep1 & & 0.0154597 & & 0.0157762 & & 0.0113205 \\
\hline ppvt_prep2 & & 0.0225189 & & 0.0224531 & & 0.0132735 \\
\hline ppvt_prep3 & & -0.063712 & & -0.0639547 & & -0.0784216 \\
\hline mou_prepo & -0.017343 & -0.019261 & -0.0175515 & -0.0194822 & -0.0642439 & -0.0695861 \\
\hline mou_prep1 & -0.0093783 & -0.0090615 & -0.0097787 & -0.0094651 & -0.0773891 & -0.0703042 \\
\hline mou_prep2 & -0.0020394 & -0.0030186 & -0.0024968 & -0.0034763 & $-0.1439003 *$ & $-0.1470565 *$ \\
\hline mou_prep3 & $-0.0604468 *$ & $-0.0604699 *$ & $-0.0606239 *$ & $-0.060649 *$ & -0.1188389 & -0.1174509 \\
\hline MOU & -0.0262288 & -0.0259134 & -0.0264213 & -0.0261161 & $-0.0688614 *$ & -0.0646987 \\
\hline SOFTLN & -0.0166632 & -0.0171762 & -0.0205068 & -0.0210318 & -0.0403302 & -0.0438438 \\
\hline LASSET & -0.0143203 & -0.0143711 & -0.0176559 & -0.0177116 & $-0.0679489 * *$ & $-0.066495^{* *}$ \\
\hline EXINT & -0.0006039 & -0.0006049 & -0.0006948 & -0.000696 & $-0.2849175 * * *$ & $-0.2834066 * * *$ \\
\hline DEPINT & -0.0012204 & -0.0012021 & -0.0016079 & -0.0015715 & -0.0016327 & -0.0016212 \\
\hline GRGDP constant price & $-0.0078698 * * *$ & $-0.0079771 * * * \|$ & $-0.0077788 * * *$ & $-0.0078896 * * * \|$ & $-0.0102562 * * *$ & $-0.0106921 * * *$ \\
\hline$\alpha 2$ & $0.1818865 * * *$ & $0.1817683 * * * \|$ & NA & NA\| & NA & $\mathrm{NA}$ \\
\hline$\alpha 3$ & $0.2951396 * * *$ & $0.2944019 * * * \|$ & $0.1156574 * *$ & $0.1150371^{* *}$ & NA & NA \\
\hline industry effects & Included & Included & Included & Included & Included & Included \\
\hline Adj. R-sqr & 0.134 & 0.135 & 0.1236 & 0.1246 & 0.3022 & 0.3048 \\
\hline No. of Observations & 3062 & $3062 \|$ & 2923 & 2923|| & 889 & 889 \\
\hline
\end{tabular}

Note. Source: Author's calculation using data from Public Enterprise Survey (1990-2015).

*Significance at $10 \%$ level; **Significance at 5\% level; *** Significance at $1 \%$ level. 
Table 4a

Regression for Value Added per Asset (VAA) MOU Effect (1990-2015)

\begin{tabular}{|c|c|c|c|c|c|c|}
\hline \multirow[t]{2}{*}{ Variables } & \multicolumn{2}{|c|}{ Sub-Sample S1 } & \multicolumn{2}{|c|}{ Sub-Sample S2 } & \multicolumn{2}{|c|}{ Sub-Sample S3 } \\
\hline & (i) & (ii) & (iii) & (iv) & (v) & (vi) \\
\hline Intercept & 0.0936028 & 0.0952819 & $0.2574034^{* * *}$ & $0.2659574^{* * *}$ & $0.2581818^{* * *}$ & $0.262715^{* * *}$ \\
\hline mou_prep0 & & -0.0175408 & & -0.0176365 & & -0.0121414 \\
\hline mou_prep1 & & -0.0146687 & & -0.0154325 & & -0.008323 \\
\hline mou_prep2 & & -0.0226129 & & -0.0238348 & & -0.0145553 \\
\hline mou_prep3 & & $-0.0432859 *$ & & $-0.0445908 * *$ & & -0.0353317 \\
\hline MOU & -0.0211249 & $-0.0253886 *$ & -0.020817 & $-0.0252154 *$ & -0.0226571 & -0.0252766 \\
\hline SOFTLN & 0.0112711 & 0.0121075 & 0.0047442 & 0.0055124 & 0.0147281 & 0.0151082 \\
\hline LASSET & $-0.0337779 * * *$ & $-0.0369017 * * * \|$ & $-0.0373183 * * *$ & $-0.0408755^{* * *}$ & $-0.0344595 * * *$ & $-0.0364265^{* * *}$ \\
\hline EXINT & -0.0001944 & -0.0002032 & -0.0001151 & -0.0001242 & -0.0001125 & -0.0001186 \\
\hline DEPINT & -0.0006203 & -0.0006199 & -0.0143479 & -0.0143934 & -0.0138563 & -0.0139164 \\
\hline GRGDP constant price & $-0.0065352 * * *$ & $-0.0061493 * * * \|$ & $-0.0058853 * * *$ & $-0.0054484 * * *$ & $-0.0070295 * * *$ & $-0.0066907 * * *$ \\
\hline$\alpha 2$ & $0.1598485^{* * *}$ & $0.1660002^{* * *} \|$ & NA & $\mathrm{NA}$ & NA & NA \\
\hline$\alpha 3$ & $0.2957047^{* * *}$ & $0.3059543 * * *$ & $0.1492176^{* * *}$ & $0.1536461^{* * *}$ & NA & NA \\
\hline industry effects & Included & Included & Included & Included & Included & Included \\
\hline Adj. R-sqr & 0.1726 & 0.1721 & 0.1598 & 0.159 & 0.1798 & 0.1794 \\
\hline No. of Observations & 2677 & 2677 & 2540 & 2540 & 2240 & 2240 \\
\hline
\end{tabular}

Note. Source: Author's calculation using data from Public Enterprise Survey (1990-2015).

*Significance at $10 \%$ level; **Significance at 5\% level; *** Significance at $1 \%$ level.

Table $4 \mathrm{~b}$

Regression for Value Added per Asset (VAA) Disinvestment Effect (1990-2015)

\begin{tabular}{|c|c|c|c|c|c|c|}
\hline Variables & Sub-San & mple S4 & Sub-Sar & nple S5 & Sub-San & mple S6 \\
\hline & (i) & (ii) & (iii) & (iv) & (v) & (vi) \\
\hline Intercept & $0.1302193 * *$ & $0.1355729 * *$ & $0.3229232 * * *$ & $0.3306753 * * *$ & $0.547848 * * *$ & $0.547375 * * *$ \\
\hline ppvt_dummy & $0.0364425 * *$ & $0.1026553 * * *$ & $0.0372656 * *$ & $0.10265^{* * *}$ & $0.0582224 * * *$ & $0.1334707 * * *$ \\
\hline ppvt_prep1 & & $0.1184834 * * *$ & & $0.1172944 * * *$ & & $0.1262605 * * *$ \\
\hline ppvt_prep2 & & $0.1109643 * * *$ & & $0.1090175^{* * *}$ & & $0.1123936 * * *$ \\
\hline ppvt_prep3 & & 0.056133 & & 0.0554201 & & 0.0534209 \\
\hline mou_prepo & -0.0140366 & -0.016015 & -0.0143358 & -0.0162856 & -0.0181689 & -0.0302529 \\
\hline mou_prep1 & -0.0115423 & -0.0128845 & -0.0123172 & -0.0136472 & -0.0222858 & -0.0314619 \\
\hline mou_prep2 & -0.024386 & -0.0241876 & -0.024951 & -0.0247419 & -0.0840862 & -0.0826154 \\
\hline mou_prep3 & $-0.043374 *$ & $-0.0403814^{*}$ & $-0.0440091^{* *}$ & $-0.0410532 *$ & -0.099198 & -0.0723331 \\
\hline MOU & -0.0225206 & -0.0233803 & -0.0224855 & -0.0233556 & -0.0246282 & -0.0311409 \\
\hline SOFTLN & 0.0011931 & 0.0026271 & -0.0049472 & -0.0035431 & -0.0249063 & -0.0165305 \\
\hline LASSET & $-0.057936 * * *$ & $-0.0610423 * * *$ & $-0.0623323 * * *$ & $-0.0655174 * * *$ & $-0.1051901 * * *$ & $-0.1260956 * * *$ \\
\hline EXINT & -0.0002051 & -0.0002067 & -0.0001852 & -0.0001871 & $-0.1551243 * * *$ & $-0.1323275^{* * *}$ \\
\hline DEPINT & $-0.0032213 * * *$ & $-0.0031857 * * *$ & $-0.0062682 * * *$ & $-0.0062065 * * *$ & $-0.0062254 * * *$ & $|-0.0062509 * * *|$ \\
\hline GRGDP constant price & $-0.0070121 * * *$ & $-0.0071642 * * *$ & $-0.006522 * * *$ & $-0.0066718^{* * *}$ & $-0.0072779 * * *$ & $-0.0077778 * * *$ \\
\hline$\alpha 2$ & $0.1860889 * * *$ & $0.1883246^{* * *}$ & NA & NA & NA & NA \\
\hline$\alpha 3$ & $0.2885252^{* * *}$ & $0.236355^{* * *}$ & $0.1152371 * * *$ & $0.0615614 *$ & $\mathrm{NA}$ & $\mathrm{NA}$ \\
\hline industry effects & Included & Included & Included & Included & Included & Included \\
\hline Adj. R-sqr & 0.188 & 0.1909 & 0.1666 & 0.1692 & 0.2889 & 0.2966 \\
\hline No. of Observations & 3216 & 3216 & 3079 & 3079 & 891 & 891 \\
\hline
\end{tabular}

Note. Source: Author's calculation using data from Public Enterprise Survey (1990-2015).

*Significance at $10 \%$ level; **Significance at 5\% level; *** Significance at $1 \%$ level. 
Table 4c

Regression for Value Added per Asset (VAA) Private Equity Effect (1990-2015)

\begin{tabular}{|c|c|c|c|c|c|c|}
\hline \multirow[t]{2}{*}{ Variables } & \multicolumn{2}{|c|}{ Sub-Sample S4 } & \multicolumn{2}{|c|}{ Sub-Sample S5 } & \multicolumn{2}{|c|}{ Sub-Sample S6 } \\
\hline & (i) & \begin{tabular}{|l|} 
(ii) \\
\end{tabular} & (iii) & (iv) & (v) & (vi) \\
\hline Intercept & $0.1447084 * *$ & $0.1456418 * *$ & $0.345059 * * *$ & $0.3453838 * * *$ & $0.542859 * * *$ & $0.547195^{* * *}$ \\
\hline ppvt_shr & 0.0641623 & $0.101087^{*}$ & 0.070399 & $0.1074417^{* *}$ & 0.1158683 & $0.1805307^{* *}$ \\
\hline ppvt_prep1 & & $0.0528313 *$ & & $0.0523872 *$ & & $0.0559589 * *$ \\
\hline ppvt_prep2 & & 0.0450971 & & 0.0438982 & & 0.0473373* \\
\hline ppvt_prep3 & & 0.0058589 & & 0.0055349 & & 0.0001588 \\
\hline mou_prep0 & -0.0206096 & -0.0237299 & -0.0209546 & -0.0240064 & -0.0357061 & -0.0517509 \\
\hline mou_prep1 & -0.0105858 & -0.0129954 & -0.0114421 & -0.0138001 & -0.0448145 & -0.0591699 \\
\hline mou_prep2 & -0.0212065 & -0.022768 & -0.021972 & -0.0235043 & $-0.1079723 * *$ & $-0.1211985 * *$ \\
\hline mou_prep3 & $-0.0445613^{*}$ & $-0.044073 *$ & -0.0452137 & $-0.0447388 * *$ & -0.1105816 & -0.1069119 \\
\hline MOU & $-0.0286192 * *$ & $-0.0304762 * *$ & $-0.0286174 * *$ & $-0.0304408 * *$ & -0.0351891 & -0.0431302 \\
\hline SOFTLN & -0.0005734 & -0.0009167 & -0.0070470 & -0.0074458 & -0.0305259 & -0.0311 \\
\hline LASSET & $-0.0608828 * * *$ & $-0.0609205^{* * *}$ & $-0.0656539 * * *$ & $-0.0657862 * * *$ & $-0.0952227 * * *$ & $-0.1002045^{* * *}$ \\
\hline EXINT & $-0.000612 *$ & $-0.0006132 *$ & $-0.0006631 *$ & $-0.0006645 *$ & $-0.1613791 * * *$ & $-0.1551633 * * *$ \\
\hline DEPINT & $-0.0031999 * * *$ & $-0.0031547 * * *$ & $-0.0062303 * * *$ & $-0.0061448 * * *$ & $-0.0061107 * * *$ & $-0.0060583 * * *$ \\
\hline GRGDP constant price & $-0.0073797 * * *$ & $-0.0074278 * * *$ & $-0.0069162 * * *$ & $-0.0069596 * * *$ & $-0.0076605 * * *$ & $-0.0081229 * * *$ \\
\hline$\alpha 2$ & $0.1926512 * * *$ & $0.1918575^{* * *}$ & $\mathrm{NA}$ & $\mathrm{NA}$ & NA & NA \\
\hline$\alpha 3$ & $0.300978 * * *$ & $0.2934732 * * *$ & $0.1216123 * * *$ & $0.1151829 * * *$ & NA & NA \\
\hline industry effects & Included & Included & Included & Included & Included & Included \\
\hline Adj. R-sqr & 0.2011 & 0.2039 & 0.1795 & 0.1823 & 0.2959 & 0.3037 \\
\hline No. of Observations & 3170 & 3170 & 3035 & 3035 & 891 & 891 \\
\hline
\end{tabular}

Note. Source: Author's calculation using data from Public Enterprise Survey (1990-2015).

*Significance at $10 \%$ level; **Significance at 5\% level; *** Significance at $1 \%$ level.

The coefficients of the dummy variable $\alpha 2$ for Type 2 firms which signed an MoU are positive, which suggests Type 1 firms have on average lower VAA compared to Type 2 firms. The coefficient for the dummy variable $\alpha 3$, which controls for group effects of firms that had some privatization, is also positive and highly significant. This shows that on average VAA is higher for Type 3 firms compared to Type 2 firms. These variables were introduced to remove selection bias.

Finally, we also analyze net sales per asset (NSA) as a measure of efficiency of the firm. The results in Tables $5 \mathrm{a}, 5 \mathrm{~b}$, and $5 \mathrm{c}$ show that MOU has no effect on performance. But disinvestment has a very positive effect on firm efficiency. Larger firms are less efficient as the coefficient of size is negative and significant. Greater export orientation has a negative effect on NSA and more capital intensity has a negative effect which we measure by the share of depreciation. We also see that GDP growth has a positive impact on NSA which is to be expected as demand for products rises in a faster growing economy. 
Table 5a

Regression Net Sales per Asset (NSA) MOU Effect (1990-2015)

\begin{tabular}{|c|c|c|c|c|c|c|}
\hline Variables & Sub-San & mple S1 & Sub-San & nple S2 & Sub-San & nple S3 \\
\hline & (i) & (ii) & (iii) & (iv) & (v) & (vi) \\
\hline Intercept & $0.4700819^{* *}$ & $0.4764372^{* *}$ & $0.6324914 * * *$ & $0.6665434 * * *$ & $0.6491935 * * *$ & $0.6705172 * * *$ \\
\hline mou_prep0 & & -0.0431966 & & -0.0329884 & & -0.012731 \\
\hline mou_prep1 & & $-0.0754307 *$ & & $-0.077043^{* *}$ & & -0.0608721 \\
\hline mou_prep2 & & $-0.1468405 * * *$ & & $-0.1505047 * * *$ & & $-0.1270821 * *$ \\
\hline mou_prep3 & & $-0.1872663 * * *$ & & $-0.1938496 * * *$ & & $-0.1758239 * * *$ \\
\hline MOU & -0.0154951 & -0.0336814 & -0.0152651 & -0.0328552 & -0.0074218 & -0.0205991 \\
\hline SOFTLN & -0.0151677 & -0.0139235 & -0.0175496 & -0.016667 & -0.0157277 & -0.0155974 \\
\hline LASSET & $-0.0699272 * * *$ & $-0.0859553 * * * \mid$ & $-0.0860077 * * *$ & $-0.1024329 * * *$ & $-0.0781492 * * * \mid$ & $-0.0901201 * * *$ \\
\hline EXINT & $-0.0013926 * * *$ & $-0.0014349 * * * \mid$ & $-0.0008478 * *$ & $-0.0008926 * *$ & $-0.0008474 * *$ & $-0.0008813^{* *}$ \\
\hline DEPINT & -0.0047206 & -0.0047437 & $-0.096514 * * *$ & $-0.0961587 * * *$ & $-0.0952264 * * *$ & $-0.095411 * * *$ \\
\hline GRGDP constant price & $0.0076986 * *$ & $0.009818^{* *}$ & $0.0104364 * * *$ & $0.0128012 * * *$ & 0.0081973* & $0.0105413^{* *}$ \\
\hline$\alpha 2$ & 0.1393024 & 0.1684783 & NA & NA & $\mathrm{NA}$ & NA \\
\hline$\alpha 3$ & $0.3316639 * *$ & $0.3780871^{* *}$ & $0.2089087^{* *}$ & $0.2254308^{* *}$ & $\mathrm{NA}$ & NA \\
\hline industry effects & Included & Included & Included & Included & Included & Included \\
\hline Adj. R-sqr & 0.2708 & 0.2744 & 0.2937 & 0.2976 & 0.2805 & 0.2835 \\
\hline No. of Observations & 2696 & 2696 & 2550 & 2550 & 2241 & 2241 \\
\hline
\end{tabular}

Note. Source: Author's calculation using data from Public Enterprise Survey (1990-2015).

*Significance at $10 \%$ level; **Significance at 5\% level; *** Significance at $1 \%$ level.

Table $5 b$

Regression Net Sales per Asset (NSA) Disinvestment Effect (1990-2015)

\begin{tabular}{|c|c|c|c|c|c|c|}
\hline \multirow[t]{2}{*}{ Variables } & \multicolumn{2}{|c|}{ Sub-Sample S4 } & \multicolumn{2}{|c|}{ Sub-Sample S5 } & \multicolumn{2}{|c|}{ Sub-Sample S6 } \\
\hline & (i) & (ii) & (iii) & (iv) & (v) & (vi) \\
\hline Intercept & $0.4620753^{* *}$ & $0.4693645^{* *}$ & $0.6208374 * * *$ & $0.631205^{* * *}$ & 0.5112547 & 0.5037802 \\
\hline ppvt_dummy & $0.1290758 * * *$ & $0.2191388 * * *$ & $0.1338202 * * *$ & $0.2242002 * * *$ & $0.0869655 * *$ & $0.1778847 * * *$ \\
\hline ppvt_prep1 & & 0.113963 & & 0.1152548 & & 0.0997122 \\
\hline ppvt_prep2 & & $0.1874123^{* *}$ & & $0.1869379 * *$ & & $0.1833993 * * *$ \\
\hline ppvt_prep3 & & 0.0980761 & & 0.100593 & & 0.069289 \\
\hline mou_prep0 & -0.0272051 & -0.030045 & -0.0274425 & -0.0302456 & -0.0355586 & -0.0525644 \\
\hline mou_prep1 & -0.0563963 & -0.0590297 & -0.059096 & -0.0617543 & -0.030556 & -0.0456736 \\
\hline mou_prep2 & $-0.1425298 * * *$ & $-0.1435577 * * *$ & $-0.1450906 * * *$ & $-0.1460657 * * *$ & $-0.2656374 * *$ & $-0.2788926 * * *$ \\
\hline mou_prep3 & $-0.1848095 * * *$ & $-0.1807506^{* * *}$ & $-0.1879647 * * *$ & $-0.1838707^{* * *}$ & $-0.3231676 * *$ & $-0.2893631^{* *}$ \\
\hline MOU & -0.0276678 & -0.0272376 & -0.0280505 & -0.0276732 & -0.0390891 & -0.0389229 \\
\hline SOFTLN & -0.0151438 & -0.0146884 & -0.0173724 & -0.0169217 & $-0.1769657 * * *$ & $-0.1622062 * * *$ \\
\hline LASSET & $-0.0654842 * * *$ & $-0.0695947 * * *$ & $-0.077581 * * *$ & $-0.081738^{* * *}$ & -0.0409528 & -0.0626605 \\
\hline EXINT & $-0.0014151 * * *$ & $-0.0014175 * * *$ & $-0.0013538 * * *$ & $-0.0013566 * * *$ & 0.0239358 & 0.0535768 \\
\hline DEPINT & $-0.0057814 * * *$ & $-0.005733 * * *$ & $-0.010057 * * *$ & $-0.0099642 * * *$ & $-0.0062832 * *$ & $-0.0063046 * *$ \\
\hline GRGDP constant price & $0.0086693 * *$ & $0.008416^{* *}$ & $0.0104853 * * *$ & $0.0102284 * * *$ & 0.0071721 & 0.0062224 \\
\hline$\alpha 2$ & 0.1419706 & 0.1449833 & NA & NA & NA & NA \\
\hline$\alpha 3$ & $0.3028812 *$ & 0.2314704 & $0.1760326 *$ & 0.1011627 & NA & NA \\
\hline industry effects & Included & Included & Included & Included & Included & Included \\
\hline Adj. R-sqr & 0.3492 & 0.3505 & 0.3631 & 0.3644 & 0.7074 & 0.7093 \\
\hline No. of Observations & 3228 & 3228 & 3082 & 3082 & 893 & 893 \\
\hline
\end{tabular}

Note. Source: Author's calculation using data from Public Enterprise Survey (1990-2015).

*Significance at $10 \%$ level; **Significance at 5\% level; *** Significance at $1 \%$ level. 
Table 5c

Regression Net Sales per Asset (NSA) Private Equity Effect (1990-2015)

\begin{tabular}{|c|c|c|c|c|c|c|}
\hline Variables & \multicolumn{2}{|c|}{ Sub-Sample S4 } & \multicolumn{2}{|c|}{ Sub-Sample S5 } & \multicolumn{2}{|c|}{ Sub-Sample S6 } \\
\hline & (i) & (ii) & (iii) & (iv) & (v) & \begin{tabular}{|l} 
(vi) \\
\end{tabular} \\
\hline Intercept & $0.5442003^{* * *}$ & $0.54436 * * *$ & $0.7469765^{* * *}$ & $0.7462294^{* * *}$ & 0.557172 & 0.559231 \\
\hline ppvt_shr & $0.4228285^{* * *}$ & $0.4543925^{* * *}$ & $0.4257005^{* * *}$ & $0.4544601 * * *$ & $0.2635199 * * *$ & $0.3306599 * *$ \\
\hline ppvt_prep1 & & 0.0003674 & & -0.0022132 & & 0.0122526 \\
\hline ppvt_prep2 & & 0.0742417 & & 0.0699556 & & $0.1034338^{*}$ \\
\hline ppvt_prep3 & & 0.0070396 & & 0.006677 & & 0.0014073 \\
\hline mou_prepo & $-0.0564793 *$ & $-0.0593951 *$ & $-0.0571779 *$ & $-0.0598536 *$ & -0.0624600 & -0.0854449 \\
\hline mou_prep1 & $-0.0664741 *$ & $-0.0689744 * * \|$ & $-0.0698011 * *$ & $-0.0721105^{* *}$ & -0.068017 & -0.0902385 \\
\hline mou_prep2 & $-0.1478261 * * *$ & $-0.1506089 * * *$ & $-0.1509447 * * *$ & $-0.1535698 * * *$ & $-0.3078012 * * *$ & $-0.3412084 * * *$ \\
\hline mou_prep3 & $-0.1725013^{* * *}$ & $-0.1721324 * * *$ & $-0.1757379 * * *$ & $-0.1753921 * * *$ & $-0.3463651 * *$ & $-0.3445991^{* *}$ \\
\hline $\mathrm{MOU}$ & -0.0527834 & -0.0525871 & -0.0535846 & -0.0532893 & -0.0548119 & -0.0572858 \\
\hline SOFTLN & -0.0135 & -0.0133761 & -0.0159885 & -0.0158666 & $-0.1799605 * * *$ & $-0.1775295^{* * *}$ \\
\hline LASSET & $-0.096988 * * *$ & $-0.0965476 * * *$ & $-0.109592^{* * *}$ & $-0.1091493 * * * \|$ & -0.0478421 & -0.051246 \\
\hline EXINT & -0.0011203 & -0.0011213 & -0.0007479 & -0.0007492 & 0.0159920 & 0.0249515 \\
\hline DEPINT & $-0.0056106 * * *$ & $-0.0055729 * * * \|$ & $-0.0097267 * * *$ & $-0.0096609 * * *$ & $-0.0062141 * *$ & $-0.0061569 * *$ \\
\hline GRGDP constant price & $0.0071081 * *$ & $0.0070029 * *$ & $0.0089624 * * *$ & $0.008861 * * *$ & 0.0067613 & 0.0059015 \\
\hline$\alpha 2$ & 0.1853393 & 0.1844862 & NA & NA & NA & NA \\
\hline$\alpha 3$ & $0.3241705^{* *}$ & $0.3174403^{* *}$ & 0.1567298 & 0.1514245 & NA & NA \\
\hline industry effects & Included & Included & Included & Included & Included & Included \\
\hline Adj. R- sqr & 0.3952 & 0.3959 & 0.4089 & 0.4095 & 0.7111 & 0.7128 \\
\hline No. of Observations & 3181 & 3181 | - - - - & 3038 & 3038 & 893 & 893 \\
\hline
\end{tabular}

Note. Source: Author's calculation using data from Public Enterprise Survey (1990-2015)

*Significance at $10 \%$ level; **Significance at 5\% level; *** Significance at $1 \%$ level

\section{Conclusions}

In this paper, the focus is on policy variables and factors affecting the efficiency and productivity of India's PSUs using various measures of value added. In an earlier paper (Chhibber \& Gupta, 2017), in which the focus was on financial rates of return, both performance contracts and disinvestment were seen to be important policy variables. In this paper, value added per employee is used as a measure of labour productivity and value added per capital and value added per asset to measure productive use of capital and assets. The model used ensures correction for self-selection. The results show that $\mathrm{MoU}$ - performance contracts have no positive and sometimes negative effect on performance. On the other hand, disinvestment measured by a privatization dummy in the year of disinvestment and the share of private equity has a very positive effect on these productivity measures.

The results provide very clear support for disinvestment as opposed to use of performance contracts to improve the performance of PSUs. Even if the objective of disinvestment is to raise revenue for the budget rather than a tool for improving performance of the PSU, the paper shows that it does improve both labour productivity and capital/asset productivity. Using disinvestment proceeds to finance the recurrent budget is a questionable practice. Instead disinvestment proceeds should be allocated to the recently created National Infrastructure Strategic Fund (NISF), which can then be used to finance infrastructure projects.

Larger PSUs - the so called 7 Maharatnas and 17 Navratnas were considered better performers but their value added per asset and net sales per asset are significantly lower than even the smaller PSUs. They have 
higher labour productivity but that simply comes from greater capital intensity in these large PSUs. For these firms, the government needs to prepare a strategic plan and decide if they can become world class companies. For those that cannot should also be privatized to extract better value for assets.

In any case, the present paper shows that a bolder roadmap for gradually getting the government out of the business of business, must be prepared with a hard look at the real economic benefits from some of the profit-making State-owned firms, as well. The question to be asked is, are these firms locking up scarce capital to provide employment for a few, or can they become strategic world-class companies? The recent decision to sell Air India is one such bold decision. The argument that Air India is profitable and is only in trouble because of past debt, is not relevant, as the issue is not profitability but efficient and productive use of assets.

Such a bold approach to transferring State-owned assets with generally low return towards public social infrastructure is a win-win idea, especially because the private sector will improve efficiency. The second gain is it will unlock funds for building badly-needed social infrastructure - roads, power transmission lines, sewage systems, irrigation systems, railways and urban infrastructure. This will also help draw in private investment, including FDI.

So far India has no clear strategy in dealing with PSUs - it has followed a case by case approach - although more recently, with the decision to privatize Air India, it appears that the government is getting more serious about privatization. If the Modi government wants to leave behind a lasting transformation of the economy, getting the government out of business and laying a foundation for rapid growth by accelerating India's infrastructure plans is the way forward. Develop a 10 -year plan to divest at least $50 \%$ of PSU assets, shift the proceeds into the strategic investment fund and reap the rewards. The business of the government is public infrastructure, not public companies. Transforming public assets into public infrastructure would be a lasting reform.

\section{References}

Arun, T. G. \& Nixson, F. I. (2000). The disinvestment of public sector enterprises: the Indian experience. Oxford Development Studies, 28(1), 19-32.

Bhagwati, J. \& Srinivasan, T. N. (1993). India's Economic Reforms. New Delhi, India: Ministry of Finance, Government of India.

Bombay Stock Exchange Disinvestments Database (March 2015). Retrieved from https://www.bseindia.com/market_data.html

Chhibber, A. \& Gupta, S. (2017). Public Sector Undertakings: Bharat's Other Ratnas. Working paper No. 186. New Delhi, India: National Institute of Public Finance and Policy.

Department of Disinvestment (2015). Disinvestment till March 3, 2016.

D'souza, J. \& Megginson, W. L. (1999). The financial and operating performance of privatized firms during the 1990s. The Journal of Finance, 54(4), 1397-1438.

Gunasekar, S. \& Sarkar, J. (2014). Does autonomy matter in State owned Enterprises? Evidence from performance contracts in India. IGIDR Working Paper WP-2014-034. Mumbai, India: Indira Gandhi Institute of Development Research.

GSCPE. (2017). Is the Private Sector more Efficient? UNDP, Singapore: Global Centre for Public Service Excellence.

Gupta, N. (2005). Partial privatization and firm performance. The Journal of Finance, 60(2), 987-1015. 
Gupta, N. (2011). Selling the family silver to pay the grocer's bill? The case of privatization in India. Available at https://kelley.iu.edu/nagupta/gupta_mar2011.pdf

Jain, R. (2016). Do political factors influence performance of Public Sector Enterprises? The Indian Disinvestment Experience. 12th Annual Conference on Economic Growth and Development, ISI Delhi, December 2016.

Mathur, B. M. D. R. (2010). Accountability and Autonomy Relationship in Central Public Sector Enterprises (CPSES) In India through Memorandums of Understanding (MoUs). In International Conference on Applied Economics - ICOAE (p. 495).

Megginson, W. L. \& Netter, J. M. (2001). From State to Market: A Survey of Empirical Studies on Privatization. Journal of Economic Literature, 39(2), 321-389.

Muhlenkamp, H. (2013). From State to Market revisited: more empirical evidence on the efficiency of public (and privately owned) enterprises [MPRA Paper]. Retrieved from mpra.ub.unimuenchen.de/47570/

Mukherjee, A. (2015). Services sector in India: trends, issues, and the way forward. Eurasian Geography and Economics, 56(6), 635-655.

Nagaraj, R. (2005). Disinvestment and Privatization in India: Assessment and Options. Asian Development Bank Policy Networking Project, New Delhi, India.

NCAER. (2004). Study on the revamping of the MoU System. New Delhi, India: National Council of Applied Economic Research.

Seema, G., Jain, P. K., Yadav, S. S., \& Gupta, V. K. (2011). Financial performance of disinvested central public sector enterprises in India: An empirical study on select dimensions. Journal of Applied Finance and Banking, 1(4), 57.

Sharma, G. L. (2013). Public Sector Enterprises and the Memorandum of Understanding: Charting New Frontiers. Working Paper. Delhi, India: Lal Bahadur Shastri Institute of Management.

Shirley, M. M. \& Xu, L. C. (1998). Information, incentives, and commitment: An empirical analysis of contracts between government and state enterprises. Journal of Law, Economics, \& Organization, 14(2), 358-378.

Shirley, M. M. \& Xu, L. C. (1998). The empirical effects of performance contracts: evidence from China (No. 1919). World Bank Publications.

Trivedi, P. (1990). Lack of Understanding on Memorandum of Understanding. Economic and Political Weekly, M175-M182.

Various Public Enterprises Survey Reports. (1987-2015). Department of Public Enterprises, Government of India.

\section{Authors Note}

Correspondence concerning this article should be addressed to Ajay Chhibber, Institute of International Economic Policy, George Washington University, Suite 501, 1957 E street, NW, Washington DC 20052, Email: ajaychhibber9@gmail.com; and to Swati Gupta, Shiv Nadar University, India, Email: swatigupt90@gmail.com

\section{Biographical Notes}

Ajay Chhibber is a Visiting Scholar, Institute of International Economic Policy, George Washington University. He was a Distinguished Visiting Professor, NIPFP, India. He held senior positions at the UN as Assistant Secretary General and the World Bank as Country Director in Vietnam and Turkey and earlier in Indonesia and the Pacific. He led the 1997 World Development Report on the Role of the State. He has 
published widely, including five books on economic development and many articles in international journals and in major newspapers. He has a Ph.D. from Stanford University and a Masters from the Delhi School of Economics.

Swati Gupta is based in New Delhi. She is pursuing independent economic research and working as a data consultant. Her research interest primarily lies in macroeconomics, public policy, development economics and econometrics. Prior to this, she worked as a Project Associate at the National Institute of Public Finance and Policy, an autonomous body under the Ministry of Finance. She obtained her M.S. Economics from Shiv Nadar University, India. 